\title{
DIGITAL PAYMENT: PERSPEKTIF GENDER DALAM PEMILIHAN JASA PEMBAYARAN DIGITAL
}

\author{
Aldilla Iradianty, Bayu Rima Aditya
}

Telkom University, Bandung, Indonesia

\begin{tabular}{|c|c|}
\hline ARTICLE INFORMATION & \multirow{10}{*}{$\begin{array}{l}\text { ABSTRAK } \\
\text { Di era digital sekarang ini, pembeli dan penjual } \\
\text { menggunakan aplikasi pembayaran digital dengan } \\
\text { pembayaran nontunai. Namun perbedaan gender } \\
\text { dapat mempengaruhi perbedaan cara antara laki-laki } \\
\text { dan perempuan dalam melakukan transaksi melalui } \\
\text { pembayaran digital. Oleh karena itu, penelitian ini } \\
\text { bertujuan untuk mengetahui perbedaan pria dan } \\
\text { wanita dalam menggunakan pembayaran digital. } \\
\text { Penelitian ini menggunakan pendekatan kuantitatif } \\
\text { dengan menggunakan survei kuesioner. Sebanyak } \\
\text { 104 konsumen ditanyai tentang pengalaman mereka } \\
\text { dalam menggunakan empat layanan pembayaran } \\
\text { digital populer di Indonesia: Dana, LinkAja, Gopay, } \\
\text { dan OVO. Untuk analisis data, penelitian ini } \\
\text { menggunakan analisis uji-t dua sampel untuk uji } \\
\text { beda. Hasil penelitian menunjukkan bahwa tidak ada } \\
\text { perbedaan antara laki-laki dan perempuan dalam } \\
\text { penggunaan pembayaran digital. }\end{array}$} \\
\hline ISSN: 2579-7204 (Online) & \\
\hline ISSN: 0216-4132 (Print) & \\
\hline DOI: 10.26487/jbmi.v18i1.13409 & \\
\hline SUBMISSION TRACK & \\
\hline Received: $20^{\text {th }}$ April, 2021 & \\
\hline Final Revision: $16^{\text {th }}$ May, 2021 & \\
\hline ble Online: & \\
\hline KATA KUNCI & \\
\hline $\begin{array}{l}\text { Digital Payment; Gender; OVO; Gopay; } \\
\text { LinkAja; Dana }\end{array}$ & \\
\hline
\end{tabular}

\section{KEYWORD \\ Digital Payment; Gender; OVO; Gopay; \\ LinkAja; Dana}

\section{CORRESPONDENCE}

Phone: 082126305599

E-mail: aldillai@telkomuniversity.ac.id

\begin{abstract}
In today's digital era, the buyer and seller were using digital payment applications with non-cash payment. However, gender differences could affect the different ways males and females make transactions through digital payments. Therefore, this study intended to investigate the differences between males and females in using digital payments. This study adopted a quantitative approach with used a questionnaire survey. A total of 104 consumers were asked about their experiences in using four popular digital payment services in Indonesia: Dana, LinkAja, Gopay, and OVO. For data analysis, this study used a t-test two-sample analysis for the difference test. The results showed that there were no differences between males and females in the use of digital payments.
\end{abstract}

\section{PENDAHULUAN}

Transaksi pembayaran biasanya melibatkan hanya dua pihak yaitu pihak pembeli dan pihak penjual, di mana yang menyatakan bahwa berhasil atau tidaknya transaksi 
tersebut adalah pihak penjual, pada era digital seperti sekarang ini para pembeli dan penjual memanfaatkan aplikasi pembayaran digital dengan transaksi pembayaran non tunai dalam bertransaksi, dan pihak yang terlibat bukan hanya pihak pembeli dan penjual tetapi juga ada pihak lain yang terlibat, yang kita sebut sebagai pihak ketiga atau pihak penyedia pembayaran digital, di mana pihak penyedia pembayaran digital dari pembeli bertugas meneruskan transaksi ke jaringan keuangan yang digunakan penjual (Vimal et al., 2020), walaupun ada banyak pihak yang terlibat dalam satu transaksi, pihak pembeli dan penjual dapat dengan cepat, aman, murah, dan real time, mengetahui bahwa transaksi yang dilakukan berhasil atau tidak menggunakan perangkat seluler masing-masing.

Teknologi seluler sekarang ini telah mengubah industri perbankan dan industri pembayaran (Deepak \& Himanshu, 2020) karena di era digital sekarang ini pembayaran dilakukan melalui aplikasi pemindahan uang, didukung dengan infrastruktur jaringan, peraturan dan prosedur, dimana pembayaran dilakukan dalam bentuk uang elektronik (e-money), dompet elektronik (e-wallet), ataupun $Q R$ Code, jenis pembayaran yang dapat dilakukan dengan digital ini, dapat berupa online, atupun offline (Talwar et al., 2020). Kehadiran transaksi pembayaran digital semakin digemari karena didukung oleh kenyamanan, ketersediaan layanan, diskon, dan poin reward (Iradianty \& Aditya, 2020) terlebih dipengaruhi oleh electronic word-of-mouth, kepercayaan, persepsi risiko (Oktaviani et al., 2019) kegunaan, pengalaman, manfaat (Prakosa \& Wintaka, 2020) dan kemudahan penggunaan (Aritonang \& Arisman, 2017; Oktaviani et al., 2019; Prakosa \& Wintaka, 2020).

Penggunaan atas jasa yang diberikan oleh pihak penyedia pembayaran digital di antaranya makanan, transportasi, toko online, toko offline, pulsa, pembelian tiket, donasi, supermarket, logistik, pembayaran tagihan, perkembangan usaha, investasi, kesehatan, dan lain-lain, sehingga manfaat dari layanan pembayaran digital ini sangat banyak dirasakan baik dari pihak pembeli maupun dari pihak penjual, merekapun akan tetap menggunakan jasa pembayaran digital di masa yang akan datang karena sangat didukung oleh faktor keamanan, kemudahan penggunaan, biaya, kegunaan, privasi, dan kenyamanan transaksi antara pihak pembeli dan penjual (Iradianty \& Aditya, 2020). 
Pihak pengguna mempunyai pilihan untuk menggunakan berbagai pihak penyedia pembayaran digital yang ada, di antaranya Gopay, OVO, LinkAja, Dana, Doku, Qren, Paytren, Shopeepay, dll. Pilihan tersebut menuntut pengguna memilih berdasarkan pada fungsi sistem pembayaran, keakraban, faktor situasional, faktor pribadi, tempat pembelian dan karakteristik, serta mereka dapat mengikuti proses keputusan yang hierarkis, di mana mereka menghilangkan alternatif berdasarkan ketersediaan atau penerimaan mereka dalam situasi tersebut, jika mereka tidak menemukan layanan dari pihak penyedia pembayaran yang dapat diterima, mereka mungkin menyerah akan usahanya untuk melakukan transaksi (Tounekti et al., 2020).

Faktor lain yang menentukan berkaitan dengan penggunaan jasa pembayaran digital ini adalah faktor kenyamanan penjual dalam menerima pembayaran dari penyedia pembayaran yang tidak mereka kenal, ataupun kebalikannya kenyamanan pembeli dalam memberikan sejumlah nilai untuk pembayaran kepada penyedia yang tidak dikenalnya (Beaumont, 2019) karena faktor kenyamanan memiliki pengaruh yang positif terhadap sikap penggunaan layanan pembayaran digital (Pratama, 2020). Masing-masing penyedia layanan pembayaran digital ini memiliki keunggulan dalam memberika layanannya, terutama dalam kualitas sistem, kualitas informasi dan kualitas layanan (Azzahra, 2020). Sementara tidak ada pengaruh dari faktor demografi (Iradianty \& Aditya, 2021), faktor penentuan penggunaan layanan mungkin akan berbeda jika dilihat dari sisi gender, mengingat kebiasaan penggunaan antara laki-laki dan perempuan beragam.

Perbedaan antara laki-laki dan perempuan dalam hal keamanan, di mana perempuan lebih memperhatikan keamanan pembayaran digital dibandingkan dengan laki-laki (Swapnil et al., 2020), dan dilihat dari kebiasaan berbelanja, bagi laki-laki penggunaan pembayaran digital ini dipengaruhi oleh kebiasaannya, sedangkan bagi perempuan dipengaruhi oleh niat perilakunya (Rahmatillah, 2018), dari kedua penelitian sebelumnya tersebut tampak ada perbedaan perilaku antara laki-laki dan perempuan, tetapi jika dilihat dari kegunaan dan kepercayaan sebenarnya tidak ada perbedaan yang signifikan dalam pembayaran digital antara laki-laki dan perempuan (Jain \& Kaur, 2020). Keberagaman kebiasaan ini akan terjadi juga terhadap pembelian yang dilakukan 
oleh laki-laki dan perempuan, dan dalam penelitian ini bertujuan membahas lebih lanjut mengenai apakah ada perbedaan pembelian menggunakan jasa pembayaran digital bagi laki-laki dan perempuan, dilihat dari jenis pembayarannya.

\section{TINJAUAN PUSTAKA}

Digital payment atau pembayaran digital adalah sebuah sistem yang di dalamnya terdapat sarana instruksi pembayaran, seperti kontrak, peraturan, teknisi dan fasilitas lainnya untuk membantu kelancaran transaki pembeli dan penjual (Tarantang et al., 2019), transaksi tersebut merupakan perpindahan uang yang disimpan, diproses, dan diterima dalam bentuk informasi digital (Lubis, 2019) dan sistem yang dibangun, menggunakan telepon pintar dengan basis internet, di mana uang yang berpindah tersebut tidak melibatkan bentuk fisik dari uang atau kita kenal dengan istilah non tunai (Saragih, 2019).

Pembayaran digital merupakan transaksi non tunai, via aplikasi yang dilakukan melalui perangkat telepon pintar, di mana di dalamnya terdapat alat pembayaran yang sah berupa uang yang disimpan dalam dompet digital berupa rekening dengan nomor yang sama dengan telepon selulernya, dan memungkinkan satu orang pemilik nomor telepon memiliki beragam aplikasi pembayaran digital. Transaksi dilakukan atas persetujuan pembeli dengan memasukkan kode tertentu dan transaksi ini dikatakan berhasil jika sejumlah uang yang ditransaksikan sudah diterima oleh pihak penjual dengan adanya pemberitahuan dari aplikasi yang digunakan oleh penjual. Pembayaran atas pembelian dilakukan atas hierarki kenyamanan dan kesediaan penjual dalam menyediakan pilihan pembayaran digital dari berbagai perusahaan jasa pembayaran digital yang ada, maka dari itu penelitian ini akan melihat perbedaan perilaku terhadap pemilihan jasa pembayaran digital berdasarkan perspektif gender.

$\mathrm{H}_{0}$ : Tidak terdapat perbedaan antara perilaku laki-laki dan perempuan dalam memilih jenis pembayaran menggunakan pembayaran digital

$\mathrm{H}_{1}$ : Terdapat perbedaan antara perilaku laki-laki dan perempuan dalam memilih jenis pembayaran menggunakan pembayaran digital 


\section{METODE PENELITIAN}

Penelitian ini akan melihat apakah ada perbedaan perilaku terhadap pemilihan jasa pembayaran digital berdasarkan laki-laki dan perempuan dengan menggunakan teknik pengambilan sampel, yaitu nonprobability sampling, dengan cara convenience sampling. Peneliti memilih empat penyedia pembayaran digital dengan pengguna aktif terbanyak dan total download terbanyak dari tahun 2019-2020 (Devita, 2020) dan yang termasuk ke dalam sampel tersebut adalah Dana, LinkAja, Gopay, dan OVO. Pengumpulan data dilakukan menggunakan Google formulir, karena bebas biaya dan mudah digunakan. Pendistribusian survei didasarkan pada membagikan link formulir langsung kepada laki-laki dan perempuan di seluruh Indonesia pengguna jasa dari penyedia pembayaran digital, di mana para responden dapat memilih jawaban lebih dari satu, karena memungkinkan bagi para responden sebagai pengguna dari keempat penyedia pembayaran digital ini. Analisis data digunakan untuk mengetahui apakah ada perbedaan antara laki-laki dan perempuan dalam melakukan pembayaran menggunakan Dana, LinkAja, Gopay, dan OVO.

\section{HASIL DAN DISKUSI}

Terdapat 104 responden pada penelitian ini, di mana jumlah profil laki-laki dan perempuan tidak jauh berbeda, laki-laki sebanyak 51,92\% dan perempuan sebanyak $48,08 \%$. Seluruh responden dilibatkan dalam penelitian ini untuk dimintai informasi tentang pengalaman dalam menggunakan berbagai jenis pembayaran, kemudian dianalisis menggunakan t-test two-sample asuming unequal variances dalam aplikasi spreadsheet, di mana responden diminta untuk memilih jawaban yang sesuai dengan kebiasaan yang dilakukannya, data tersebut dikumpulir dan diolah serta ditarik kesimpulannya.

Data dianalisis dengan pengujian statistik deskriptif menggunakan perangkat lunak Spreadsheet, yang akan menghasilkan laporan statistik, berupa nilai total, nilai maksimum, dan rangking, sebagai informasi tentang kecenderungan dan variabilitas utama data. Analisis statistik deskriptif sendiri merupakan penggambaran dengan mendeskripsikan data, disini kita akan mengetahui jenis pembayaran apa saja yang 
paling banyak dilakukan oleh lai-laki dan perempuan dan menggunakan penyediaan pembayaran apa berdasarkan nilai terbesar, sebagai berikut.

Tabel 1. Penggunaan penyedia pembayaran berdasarkan gender

\begin{tabular}{|c|c|c|c|c|c|c|c|c|c|}
\hline \multirow{2}{*}{$\begin{array}{c}\text { Jenis } \\
\text { pembayaran }\end{array}$} & \multicolumn{4}{|c|}{ Laki-Laki } & \multicolumn{4}{|c|}{ Perempuan } & \multirow[b]{2}{*}{ Total } \\
\hline & Dana & LinkAja & GoPay & OVO & Dana & LinkAja & GoPay & OVO & \\
\hline Pulsa & 6 & 9 & 17 & 14 & 12 & 14 & 18 & 17 & 107 \\
\hline Donasi & 4 & 4 & 10 & 10 & 4 & 2 & 12 & 6 & 52 \\
\hline Investasi & 10 & 0 & 2 & 2 & 10 & 0 & 1 & 2 & 27 \\
\hline Kesehatan & 11 & 0 & 1 & 2 & 14 & 0 & 8 & 5 & 41 \\
\hline Logistik & 3 & 0 & 7 & 6 & 2 & 0 & 6 & 3 & 27 \\
\hline Makanan & 3 & 3 & 35 & 30 & 0 & 3 & 43 & 37 & 154 \\
\hline $\begin{array}{l}\text { Membayar } \\
\text { tagihan }\end{array}$ & 11 & 2 & 2 & 4 & 16 & 3 & 4 & 3 & 45 \\
\hline Membeli tiket & 4 & 1 & 12 & 10 & 1 & 2 & 14 & 12 & 56 \\
\hline $\begin{array}{l}\text { Perkembangan } \\
\text { usaha }\end{array}$ & 2 & 1 & 4 & 4 & 0 & 0 & 0 & 0 & 11 \\
\hline Supermarket & 6 & 0 & 11 & 9 & 8 & 2 & 9 & 7 & 52 \\
\hline Toko offline & 8 & 4 & 14 & 16 & 6 & 1 & 16 & 15 & 80 \\
\hline Toko online & 0 & 1 & 16 & 19 & 0 & 3 & 15 & 19 & 73 \\
\hline Transfer dana & 2 & 5 & 15 & 18 & 1 & 3 & 17 & 19 & 80 \\
\hline Transportasi & 3 & 0 & 29 & 21 & 2 & 4 & 34 & 32 & 125 \\
\hline Lainnya & 25 & 26 & 10 & 13 & 1 & 18 & 4 & 4 & 101 \\
\hline Total & 98 & 56 & 185 & 178 & 77 & 55 & 201 & 181 & \\
\hline Maksimum & 25 & 26 & 35 & 30 & 16 & 18 & 43 & 37 & \\
\hline
\end{tabular}

Sumber: Data Diolah, 2021

Berdasarkan Tabel 1, terdapat lima belas jenis pembayaran yang dilakukan oleh lakilaki dan perempuan menggunakan layanan dari penyedia pembayaran digital. Hasil analisis menunjukkan bahwa, baik laki-laki maupun perempuan, paling banyak melakukan untuk jenis pembayaran makanan dengan nilai 154 dan paling sedikit untuk perkembangan usaha dengan nilai 11. Sehingga dapat disimpulkan bahwa perempuan dan laki-laki di Indonesia lebih banyak melakukan pembayaran digital sebagai pembeli dibandingkan sebagai penjual. 
Analisis terhadap laki-laki dalam melakukan pembayaran digital, mereka paling banyak menggunakan Gopay dengan nilai 185 dan yang paling sedikit adalah LinkAja dengan nilai 56. Sementara hasil analisis untuk perempuan, mereka paling banyak menggunakan Gopay sebagai penyedia pembayaran digital dengan nilai 201, dan yang paling sedikit adalah LinkAja dengan nilai 55. Maka dapat disimpulkan bahwa baik laki-laki dan perempuan sama-sama paling banyak menggunakan Gopay dalam melakukan pembayaran digital, dengan jenis layanan yang paling banyak dilakukan adalan untuk pembayaran makanan dengan menggunakan Gopay.

Selanjutnya menganalisis jenis pembayaran yang dilakukan oleh laki-laki dan perempuan berdasarkan nilai maksimumnya dan di analisis menggunakan rank \& percentile dalam aplikasi spreadsheet sebagai berikut.

Tabel 2. Jenis pembayaran berdasarkan gender

\begin{tabular}{|c|c|c|c|c|c|}
\hline \multicolumn{3}{|c|}{ Laki-laki } & \multicolumn{3}{|c|}{ Perempuan } \\
\hline Rangking & Maksimum & Jenis Pembayaran & Rangking & Maksimum & Jenis Pembayaran \\
\hline 1 & 35 & Makanan & 1 & 43 & Makanan \\
\hline 2 & 29 & Transportasi & 2 & 34 & Transportasi \\
\hline 3 & 26 & Lainnya & 3 & 19 & Toko online \\
\hline 4 & 19 & Toko online & 3 & 19 & Transfer dana \\
\hline 5 & 18 & Transfer dana & 5 & 18 & Pulsa \\
\hline 6 & 17 & Pulsa & 5 & 18 & Lainnya \\
\hline 7 & 16 & Toko offline & 7 & 16 & Membayar tagihan \\
\hline 8 & 12 & Membeli tiket & 7 & 16 & Toko offline \\
\hline 9 & 11 & Kesehatan & 9 & 14 & Kesehatan \\
\hline 9 & 11 & Membayar tagihan & 9 & 14 & Membeli tiket \\
\hline 9 & 11 & Supermarket & 11 & 12 & Donasi \\
\hline 12 & 10 & Donasi & 12 & 10 & Investasi \\
\hline 12 & 10 & Investasi & 13 & 9 & Supermarket \\
\hline 14 & 7 & Logistik & 14 & 6 & Logistik \\
\hline 15 & 4 & $\begin{array}{c}\text { Perkembangan } \\
\text { usaha }\end{array}$ & 15 & 0 & $\begin{array}{c}\text { Perkembangan } \\
\text { usaha }\end{array}$ \\
\hline
\end{tabular}

Sumber: Data Diolah, 2021

Tabel 2 menunjukkan bahwa data maksimum dari setiap jenis pembayaran yang dilakukan oleh laki-laki dan perempuan, dan telah diurutkan berdasarkan pembayaran terbanyak berdasarkan data yang ada pada Tabel 1. Terbanyak pertama, bagi laki-laki dan perempuan digunakan untuk pembayaran makanan menggunakan Gopay; terbanyak kedua bagi laki-laki dan perempuan digunakan untuk pembayaran transportasi menggunakan Gopay; terbanyak ketiga bagi laki-laki digunakan untuk pembayaran lainnya dengan menggunakan LinkAja dan terbaik ketiga dan keempat dengan jumlah 
yang sama untuk perempuan digunakan untuk pembayaran di toko online dan transfer dana dengan menggunakan OVO; terbanyak keempat bagi laki-laki digunakan untuk melakukan pembayaran toko online dengan OVO; serta terbanyak kelima bagi laki-laki digunakan untuk melakukan untuk transfer dana menggunakan OVO, dan terbanyak kelima bagi permpuan dengan nilai yang sama digunakan untuk pembayaran pulsa dengan menggunakan Gopay dan pembayaran lainnya menggunakan LinkAja.

Terbanyak keenam bagi laki-laki digunakan untuk melakukan pembelian pulsa dengan menggunakan Gopay, dan terbanyak ketujuh bagi laki-laki digunakan untuk pembayaran di toko offline menggunakan OVO, terbanyak ketujuh bagi perempuan digunakan untuk membayar tagihan dengan menggunakan Dana, dan pembayaran di toko offline dengan menggunakan Gopay. Terbanyak kedelapan penggunaan pembayaran digital yang dilakukan oleh-laki-laki adalah untuk pembelian tiket dengan menggunakan Gopay. Terbanyak kesembilan yang dilakukan oleh laki-laki adalah untuk kesehatan dan tagihan dengan menggunakan Dana, dan terbanyak kesembilan untuk perempuan adalah untuk kesehatan menggunakan Dana dan pembelian tiket dengan menggunakan Gopay. Terbanyak kesebelas untuk perempuan adalah untuk donasi dengan menggunakan Gopay.

Terbanyak keduabelas untuk laki-laki adalah pembayaran untuk donasi dengan menggunakan Gopay dan OVO, serta untuk investasi dengan menggunakan Dana. Bagi perempuan terbanyak keduabelas pembayaran adalah digunakan untuk investasi dengan menggunakan Dana. Terbanyak ketigabelas bagi perempuan digunakan untuk pembayaran di supermarket dengan menggunakan Gopay. Terbanyak keempat belas bagi laki-laki dan perempuan digunakan untuk melakukan pembayaran logistik menggunakan Gopay, terbanyak kelimabelas bagi laki-laki adalah penerimaan pembayaran dari perkembangan usaha dengan menggunakan Gopay dan OVO, sementara perempuan tidak ada yang menerima pembayaran dari perkembangan usaha ini. Selanjutnya kita akan menganalisis apakah ada perbedaan dari jenis pembayaran yang dilakukan berdasarkan persfektif gender. Dilakukan uji statistik menggunakan $t$ test two-sample asuming unequal variances. $\mathrm{H}_{0}$ ditolak jika nilai $t$ Stat $<-t$ critical twotail atau $t$-stat $>t$ critical two-tail dan $p$-value $<0.05$. 
Tabel 3. Perbedaan gender menggunakan Dana

\begin{tabular}{cc}
\hline$t$ Stat & 0.796002946 \\
$P(T<=t)$ two-tail & 0.439319716 \\
$t$ Critical two-tail & 2.144786688 \\
\hline
\end{tabular}

Sumber: Data Diolah, 2021

Dari data pada Tabel 3, didapatkan $t$ Stat $0.796002946<t$ Critical two-tail 2.144786688 dan $p$-value $0.439319716>0.05$, maka $\mathrm{H}_{0}$ diterima, yang artinya tidak terdapat perbedaan antara perilaku laki-laki dan perempuan dalam memilih jenis pembayaran menggunakan pembayaran digital Dana.

Tabel 4. Perbedaan gender menggunakan LinkAja

\begin{tabular}{cc}
\hline Stat & 0.083791785 \\
$P(T<=t)$ two-tail & 0.934408336 \\
$t$ Critical two-tail & 2.144786688 \\
\hline
\end{tabular}

Sumber: Data Diolah, 2021

Dari data pada Tabel 4 didapatkan $t$ Stat $0.083791785<t$ Critical two-tail 2.144786688 dan p-value $0.934408336>0.05$ maka $\mathrm{H}_{0}$ diterima, yang artinya tidak terdapat perbedaan antara perilaku laki-laki dan perempuan dalam memilih jenis pembayaran menggunakan pembayaran digital LinkAja.

Tabel 5. Perbedaan gender menggunakan Gopay

\begin{tabular}{cc}
\hline$t$ Stat & -1.090466621 \\
$P(T<=t)$ two-tail & 0.293920911 \\
$t$ Critical two-tail & 2.144786688 \\
\hline
\end{tabular}

Sumber: Data Diolah, 2021

Dari data pada Tabel 5 didapatkan $t$ Stat $-1.090466621<t$ Critical two-tail 2.144786688 dan p-value $0.293920911>0.05$ maka $\mathrm{H}_{0}$ diterima, yang artinya tidak terdapat perbedaan antara perilaku laki-laki dan perempuan dalam memilih jenis pembayaran menggunakan pembayaran digital Gopay.

Tabel 6. Perbedaan gender menggunakan OVO

\begin{tabular}{cc}
$t$ Stat & -0.161917351 \\
$P(T<=t)$ two-tail & 0.87368455 \\
$t$ Critical two-tail & 2.144786688 \\
\hline
\end{tabular}

Sumber: Data Diolah, 2021 
Dari data pada Tabel 6 didapatkan $t$ Stat $-0.161917351<t$ Critical two-tail 2.144786688 dan $p$-value $0.87368455>0.05$ maka $\mathrm{H}_{0}$ diterima, yang artinya tidak terdapat perbedaan antara perilaku laki-laki dan perempuan dalam memilih jenis pembayaran menggunakan pembayaran digital OVO.

\section{KESIMPULAN DAN SARAN}

Penelitian ini menyimpulkan bahwa berdasarkan pengalaman dari para pengguna Dana, LinkAja, Gopay dan OVO, dapat disimpulkan bahwa baik laki-laki maupun perempuan paling banyak melakukan pembayaran menggunakan Gopay, diikuti dengan OVO, lalu Dana, dan terakhir LinkAja. Sementara jenis pembayaran yang dilakukan diurutkan berdasarkan yang paling banyak dilakukan sebagai berikut, terbanyak pertama dan kedua baik bagi laki-laki dan perempuan digunakan untuk pembayaran makanan dan transportasi menggunakan Gopay, terbanyak ketiga bagi laki-laki digunakan untuk pembayaran lainnya dengan menggunakan LinkAja, serta terbaik ketiga untuk perempuan digunakan untuk pembayaran di toko online dan transfer dana dengan menggunakan OVO, Berdasarkan hasil uji beda yang dilakukan didapatkan hasil yang sama dari keempat pelayanan pembayaran digital, ternyata tidak terdapat perbedaan antara perilaku laki-laki dan perempuan dalam memilih jenis pembayaran menggunakan pembayaran digital.

Saran bagi perusahaan penyedia pembayaran digital dapat melakukan peningkatan terhadap layanan untuk makanan, transportasi, toko online, dan transfer dana, karena layanan ini yang paling sering digunakan pengguna. Saran bagi penjual adalah meningkatkan kolaborasi dengan pihak penyedia pembayaran digital, untuk penjual makanan, penyedia transportasi, penjual tiket, penyelenggara donasi dan provider telekomunikasi dalam menjual pulsa dapat meningkatkan kolaborasinya dengan Gopay, untuk penjual toko offline serta layanan transferdapat meningkatkan kolaborasinya dengan OVO, dan provider terkait tagihan dan kesehatan serta invertasi dapat meningkatkan kolaborasi dengan Dana. Selain itu saran bagi peneliti selanjutnya adalah mengetahui layanan lain yang sering digunakan oleh pengguna karena pengguna di dalam penelitian ini banyak memilih jawaban layanan lain yang tidak disebutkan. 


\section{DAFTAR PUSTAKA}

Aritonang, Y. A. L., \& Arisman, A. (2017). Pengaruh persepsi kemudahan dan persepsi manfaat terhadap minat menggunakan E-Money. Jurnal Akuntansi STIE Multi Data Palembang.

Azzahra, Z. (2020). Analisis Pengaruh Kualitas Sistem, Kualitas Informasi Dan Kualitas Layanan Terhadap Kepuasan Pengguna Sistem Informasi Pembayaran Menggunakan Metode Delone \& Mclean (Studi Kasus Layanan Pembayaran Go-Pay Di Aplikasi GoJek). https://openlibrary.telkomuniversity.ac.id/pustaka/160898/analisis-pengaruhkualitas-sistem-kualitas-informasi-dan-kualitas-layanan-terhadap-kepuasan-penggunasistem-informasi-pembayaran-menggunakan-metode-delone-mclean-studi-kasuslayanan-pembayaran-go-p

Beaumont, P. H. (2019). Digital Finance: Big Data, Start-ups, and the Future of Financial Services. Routledge.

Deepak, C., \& Himanshu, J. (2020). The Moderating Role Of Gender And Age In The Adoption Of Mobile Wallet. Foresight, 22(4), 483-504. https://doi.org/10.1108/FS-112019-0094

Devita, V. D. (2020). E-Wallet Lokal Masih Mendominasi Q2 2019-2020. Iprice.Co.Id.

Iradianty, A., \& Aditya, B. R. (2020). Indonesian Student Perception in Digital Payment. Jurnal Manajemen Bisnis. https://doi.org/10.38043/jmb.v17i4.2713

Iradianty, Aldilla; Aditya, B. R. (2021). Student Awareness of Digital Payment Services (Case Study in Indonesia). Journal of Physics: Conference Series, 1(1823), 012036. https://doi.org/10.1088/1742-6596/1823/1/012036

Jain, A., \& Kaur, B. (2020). Consumer Trust and Perceived usefulness on Adoption's Intent in M-Payments. 2020 8th International Conference on Reliability, Infocom Technologies and Optimization (Trends and Future Directions) (ICRITO), 526-531. https://doi.org/10.1109/ICRITO48877.2020.9197787

Lubis, N. (2019). Pengaruh Sistem Pembayaran Non-Tunai Pada Era Digital Terhadap Tingkat Inflasi Di Indonesia.

Oktaviani, R. F., Faeni, D. P., Faeni, R. P., \& Meidiyustiani, R. (2019). Implementation of mobile payment in Indonesia. International Journal of Recent Technology and Engineering. https://doi.org/10.35940/ijrte.B1172.0782S419

Prakosa, A., \& Wintaka, D. J. (2020). Analisis Faktor-Faktor yang Mempengaruhi Minat Penggunaan Ulang E-Wallet pada Generasi Milenial di Daerah Istimewa Yogyakarta. Bisman. 
Pratama, M. R. P. (2020). Pengaruh Kecemasan Teknologi Dan Sosial Terhadap Niat Menggunakan Ovo Dengan Mediasi Manfaat Layanan Pembayaran Mobile Di Bandung. https://openlibrary.telkomuniversity.ac.id/pustaka/162419/pengaruhkecemasan-teknologi-dan-sosial-terhadap-niat-menggunakan-ovo-dengan-mediasimanfaat-layanan-pembayaran-mobile-di-bandung.html

Rahmatillah, intan novirani. (2018). Analisis Pengaruh Perilaku Penggunaan Teknologi Fintech Pada Ganerasi Milenial Di Kota Bandung. Seminar Nasional VII Manajemen \& Rekayasa Kualitas 2018 ANALISIS.

Saragih, S. P. (2019). Technology Acceptance Of Digital Payment System Pada Pelaku Umkm Di Kota Batam. Computer Based Information System Journal, 7(2), 82-90.

Swapnil, U., Ashish, K., \& Harshali, P. (2020). Perceived eWallet security: impact of COVID-19 pandemic. In Vilakshan - XIMB Journal of Management: Vol. ahead-of-p (Issue ahead-of-print). https://doi.org/10.1108/XJM-07-2020-0022

Talwar, S., Dhir, A., Khalil, A., Mohan, G., \& Islam, A. K. M. N. (2020). Point of adoption and beyond. Initial trust and mobile-payment continuation intention. Journal of Retailing and Consumer Services, 55, 102086. https://doi.org/10.1016/j.jretconser.2020.102086

Tarantang, J., Awwaliyah, A., Astuti, M., \& Munawaroh, M. (2019). Perkembangan Sistem Pembayaran Digital Pada Era Revolusi Industri 4.0 Di Indonesia. JURNAL AL-QARDH. https://doi.org/10.23971/jaq.v4i1.1442

Tounekti, O., Ruiz-Martínez, A., \& Gómez, A. F. S. (2020). Users Supporting Multiple (Mobile) Electronic Payment Systems in Online Purchases: An Empirical Study of Their Payment Transaction Preferences. IEEE Access, 8, 735-766. https://doi.org/10.1109/ACCESS.2019.2961785

Vimal, K., Kuei-Kuei, L., Yu-Hsin, C., Chand, B. P., \& Fang-Pei, S. (2020). A structural analysis approach to identify technology innovation and evolution path: a case of $\mathrm{m}$ payment technology ecosystem. In Journal of Knowledge Management: Vol. ahead-of-p (Issue ahead-of-print). https://doi.org/10.1108/JKM-01-2020-0080 